\title{
A new species of Dicrepidius Eschscholtz from Brazil and new records for D. ramicornis (Palisot de Beauvois) (Coleoptera, Elateridae, Elaterinae)
}

\author{
Sonia A. Casari ${ }^{1}$ \\ ${ }^{1}$ Museu de Zoologia, Universidade de São Paulo. Caixa Postal 42494, 04218-970 São Paulo-SP, Brasil. Pesquisadora do CNPq. casari@usp.br

\begin{abstract}
A new species of Dicrepidius Eschscholtz from Brazil and new records for D. ramicornis (Palisot de Beauvois) (Coleoptera, Elateridae, Elaterinae). Dicrepidius brasilianus sp. nov., from Pará and Mato Grosso is described and illustrated. This is the second species of this genus recorded from Brazil. D. ramicornis (Palisot de Beauvois, 1805) is widely distributed from south of United States to south of Brazil. From Brazil, it was recorded from Minas Gerais, Rio de Janeiro, São Paulo and Santa Catarina states, but now other records are included. A comparison between the two Brazilian species and a discussion, including intraspecific variations, are presented.
\end{abstract}

KEYWORDS. Ampedini; description; Neotropical; taxonomy.

RESUMO. Uma nova espécie de Dicrepidius Eschscholtz do Brasil e novos registros para D. ramicornis (Palisot de Beauvois) (Coleoptera, Elateridae, Elaterinae). Dicrepidius brasilianus sp. nov., do Pará e Mato Grosso é descrita e ilustrada. Essa é a segunda espécie desse gênero registrada para o Brasil. D. ramicornis (Palisot de Beauvois, 1805) apresenta ampla distribuição, desde o sul dos Estados Unidos até o sul do Brasil. No Brasil existiam registros para os estados de Minas Gerais, Rio de Janeiro, São Paulo e Santa Catarina, mas agora novos registros são incluídos. Uma comparação entre as duas espécies brasileiras é apresentada com a discussão das variações intraespecíficas.

PALAVRAS-CHAVE. Ampedini; descrição; Neotropical; taxonomia.

The genus Dicrepidius Eschscholtz, 1829 is recognized especially by nasal bearing two inclined ridges. It is formed by 11 species, recorded from North America (United States (Arizona, Texas, Indiana, South Carolina) and Mexico), Central America (Guatemala, Belize, Nicaragua, Panama), Antilles (Cuba, Guadeloupe, Saint Vicent, Grenada) and South America (Colombia, Brazil, Argentina) (Casari, 2008). Up to now, only D. ramicornis (Palisot de Beauvois, 1805) was recorded from Brazil.

A new species, Dicrepidius brasilianus, from Pará and Mato Grosso (Brazil) is described and new records for $D$. ramicornis are presented.

The material studied belongs to collections of: Coleção de Entomologia Pe. J. S. Moure, Departamento de Zoologia Universidade Federal do Paraná (DZUP), Florida State Collection of Arthropods (FSCA), Museu Paraense Emilio Goeldi (MPEG) and Museu de Zoologia da Universidade de São Paulo (MZSP).

\section{Dicrepidius brasilianus sp. nov. (Figs. 1-18)}

Holotype male: Brasil, Mato Grosso, Nova Mutum, Faz.[enda] Buriti, 04/14-II.2002, H. F. Mendes (MZSP). Paratype female: Brasil, Pará, Serra Norte, Manganês, col. noturna, 27.I.1986; Brasil, Pará, M. F. Torres (MPEG).

Male (Fig. 17). Length: $13.97 \mathrm{~mm}$. General integument light reddish-brown; elytra yellowish with distal half blackish; hypomera yellowish; antennae brown. Pubescence fine, long, moderately dense and yellowish. Frons (Fig. 3) longer than wide (anterior width); anterior margin prominent and rounded; convex and flat medioanteriorly; punctation coarse and moderately sparse. Nasal high with two carinae convergent dorsally, not meeting at apex. Antennae long, 2.5 antennomeres longer than hind angles of pronotum; with 11 antennomeres, flabellate from 3rd antennomere (Fig. 1); 2nd antennomere transverse, last elongate. Pronotum (Fig. 5) longer than wide (from fore angles to hind angles base), wider at hind angles; moderately convex; convexity decreasing basad; lateral sutures not visible from above on anterior third; grooved and smooth longitudinal medially at base; anterior margin almost straight with fore angles prominent; hind angles divergent with apices backwards; median basal tubercle flat and rounded; punctation coarse and moderately sparse, sparser at base. Hypomera smooth, punctate only near lateral margins. Notosternal sutures almost straight, marginate by a smooth narrow band of higher integument bordered externally by a grooved line; open frontally, not making a channel. Prosternum moderately convex with punctation very coarse and sparse; prosternal lobe straight and marginate by narrow higher smooth band. Prosternal spine with subapical rounded lobe. Mesosternal cavity rounded at base; borders wide and slightly declivous on basal third and moderately declivous on anterior two thirds. Metacoxal plate (Fig. 6) slightly narrowed laterally, free margin with well developed lobe. Abdomen strong- and gradually narrowed apicad; last ventrite (Fig. 4) longer than wide with 
apex slightly rounded. Scutellum elongate and declivous with posterior margin rounded. Elytral base wider than pronotum, strongly and gradually narrowed apicad; apices (Fig. 7) narrow and truncate obliquely; punctate-striate, interstices flat; striae coarsely punctate and grooved near base. Tarsomeres 1-3 lamellate beneath; lamellae of tarsomeres 2-3 long and of tarsomere one very short.

Tergite 8 (Fig. 11) elongate, slightly narrowed to apex; distal margin rounded; punctuate and marginate by long setae. Sternite 8 (Fig. 12) as wide (at wider width) as long, wider near middle, slightly narrowed at distal half; distal margin slightly and widely notched at middle with rounded angles; translucent except a U-shaped marginal yellowish narrow band, very difficult to delimit; setae moderately long and sparse. Sternite 9 (Fig. 13) elongate; distal half gradually narrowed apicad; yellowish at distal half with indefinite limit; setous on distal third; setae longer near margins. Tergite 9 (Fig. 14) longer than wide, slight- and gradually narrowed to apex; anterior margin moderate and widely notched at middle; dense and coarsely punctate; with one seta near each distal angle. Tergite 10 elongate, slightly narrowed apicad; lateromedian region coarsely punctate and with short setae. Aedeagus (Figs. 15, 16) elongate; basal piece 1.58 time longer than parameres; parameres fused ventrally; subapical region of parameres cuneiform with long setae; median lobe (excluding basal struts) moderately longer than parameres, gradually narrowed until distal $3 / 4$ and abruptly narrowed at distal $1 / 4$.

Female (Fig. 18). Length: $16.80 \mathrm{~mm}$. Similar to male except by the integument coloration and antennal shape. General integument light reddish-brown; elytra lighter with apices blackish; antennae reddish-brown. Antennae long, three antennomeres longer than hind angles of pronotum; with 11 antennomeres; serrate (Fig. 2) from 3rd antennomere; 2nd antennomere transverse, last elongate.

Tergite 8 (Fig. 9) elongate, gradually narrowed apicad, 1.66 longer than wide; apex narrow and rounded; setous and punctated laterally near base; setae longer and more concentrate at apex. Sternite 8 (Fig. 8) elliptical and setous; setae longer and more concentrate near apex; spiculum gastrale 4.46 times longer than sternite. Apex of ovipositor broken but probably with stylus; bursa copulatrix (Fig. 10) with two toothed plates; spermatheca rounded. locality.

Etymology. The epithet is derived from the country name of type-

Remarks. Comparing Dicrepidius brasilianus sp. nov. with D. ramicornis, it was observed differences especially related to (D. ramicornis parenthesized): 1) general integument coloration light reddish-brown and brigth (dark reddishbrown); 2) elytral coloration light reddish-brown or yellowish with blackish apices (dark reddish-brown, like general integument); 3) antennae of male 2.5 antennomeres longer than hind angles of pronotum (3.7 antennomeres longer than hind angles of pronotum); 4) pronotum longer than wide (slightly wider than long); 5) punctation of pronotum coarse and moderately sparse (punctation denser); 6) borders of mesosternal cavity slightly declivous on basal third and moderately declivous on anterior two thirds (almost horizontal on basal third and moderately to strongly declivous on anterior $2 / 3$ ); 7) interstices flat (interstices slightly convex); 8) free margin of metacoxal plate with well developed lobe (with well developed tooth); 9) abdomen strongly narrowed apicad (moderately narrowed apicad); 10) sternite 8 of male wider at middle, with anterior margin notched at middle (trapezoidal); 11) basal piece of aedeagus 1.58 time parameres length (3.51 times parameres length); 12) tergite 8 of female gradually narrowed apicad, 1.66 time longer than wide (abruptly narrowed on distal third, 1.2 times longer than wide); 13) spiculum gastrale 4.46 times sternite 8 length (5.18 times sternite 8 length); 14) bursa copulatrix with two toothed plates (4 plates).

Dicrepidius brasilianus sp. nov. is recorded from Pará and Mato Grosso states (Brazil). D. ramicornis is widely distributed, with records from United States of America (Texas), Mexico (Chontales), Nicaragua, Antilles (Cuba, Guadelupe, Saint Domingue), Argentina (Chaco, Formosa) and Brazil (Palisot de Beauvois, 1805, Candèze, 1859, Chevrolat, 1867, Champion, 1894, Schenkling, 1925, Blackwelder, 1944, Bruch, 1911, Golbach, 1994, Casari, 2008). From Brazil it was recorded only from Minas Gerais, Rio de Janeiro, São Paulo and Santa Catarina states, but now it was studied material also from Amazonas, Pará, Rondônia, Mato Grosso, Mato Grosso do Sul, Ceará, Goiás, Bahia, Espírito Santo and Paraná.

Material examined. United States of America. Florida: Monroe County, Upper Key Largo (FSCA); Grassy Key (FSCA); Dade County (FSCA); Matheson (Hamm.) (FSCA). Bahamas. Andros Island: Forfar Field Station Stafford Creak (FSCA); Maidenhair Coppice (FSCA). Great Inagua: Salt Pond Hill (FSCA). Panama. Barro Colorado (MZSP). Venezuela. Lara (FSCA). French Guiana. Camp Maripe (MZSP); Montagnes Tortue (MZSP). Brazil. Amazonas: Benjamin Constant (MZSP); São Paulo de Olivença (MZSP). Pará: Serra Norte (MPEG). Rondônia: Ji-Paraná (MPEG). Mato Grosso: Salobra (Instituto Oswaldo Cruz, Zona da N.O.B.) (MZSP); Três Lagoas (margem esq. Rio Sucuriu) (MZSP). Mato Grosso do Sul: Ladário (Urucum) (MZSP). Ceará: Carquejo (MZSP). Goiás: Leopoldo Bulhões (MZSP). Bahia: Encruzilhada (DZUP); Vila Nova (MZSP). Minas Gerais: Viçosa (MZSP); Vila Monte Verde (MZSP). Rio de Janeiro: Itatiaia (MZSP); Petrópolis (DZUP, MZSP); Rio de Janeiro (Corcovado) (MZSP); Teresópolis (MZSP). Espírito Santo: Linhares (MZSP). São Paulo: Alto da Serra (MZSP); Atibaia (MZSP); Batatais (DZUP); Campinas (MZSP); Ibitinga (MZSP); Itu (Faz. Pau d'Alho) (MZSP); Pai Matias (MZSP); Pindamonhangaba (Eng. Lefevre) (MZSP); Salesópolis (Estação Biológica de Boracéia) (MZSP); São Bernardo (MZSP); São Paulo (MZSP). Paraná: Antonina (Reserva Sapitanduva) (DZUP); Colombo (DZUP); Cruz Machado (MZSP); Curitiba (MZSP); Fênix (Reserva Estadual) (DZUP); Foz do Iguaçu (DZUP); Guarapuava (DZUP); Palmas (MZSP); Ponta Grossa (DZUP, MZSP); Rio Negro (MZSP); São José dos Pinhais (DZUP). Santa Catarina: Joinvile (MZSP); Nova Teutonia (DZUP, MZSP); Rio das Antas (MZSP); São Bento do Sul (MZSP). Bolivia: El Carmen (MZSP). Argentina: Buenos Aires (S. Isidro) (MZSP); Catamarca (MZSP); El Rodeo (DZUP, MZSP); Missiones (MZSP); Salta (Guachipas, Pocitos) (MZSP).

Comparing the studied material of D. ramicornis, from different localities, several intraspecific variations were 

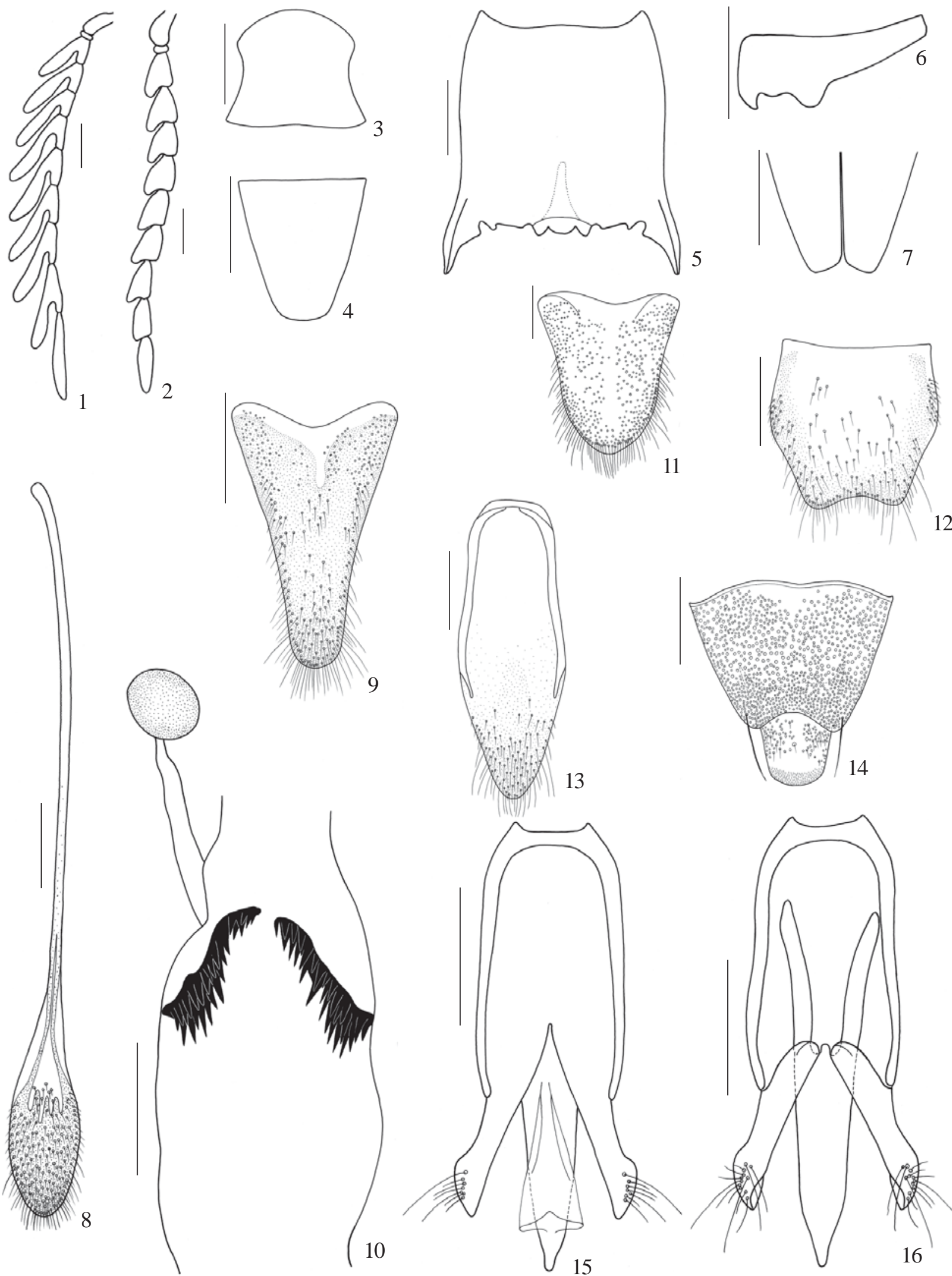

12

13
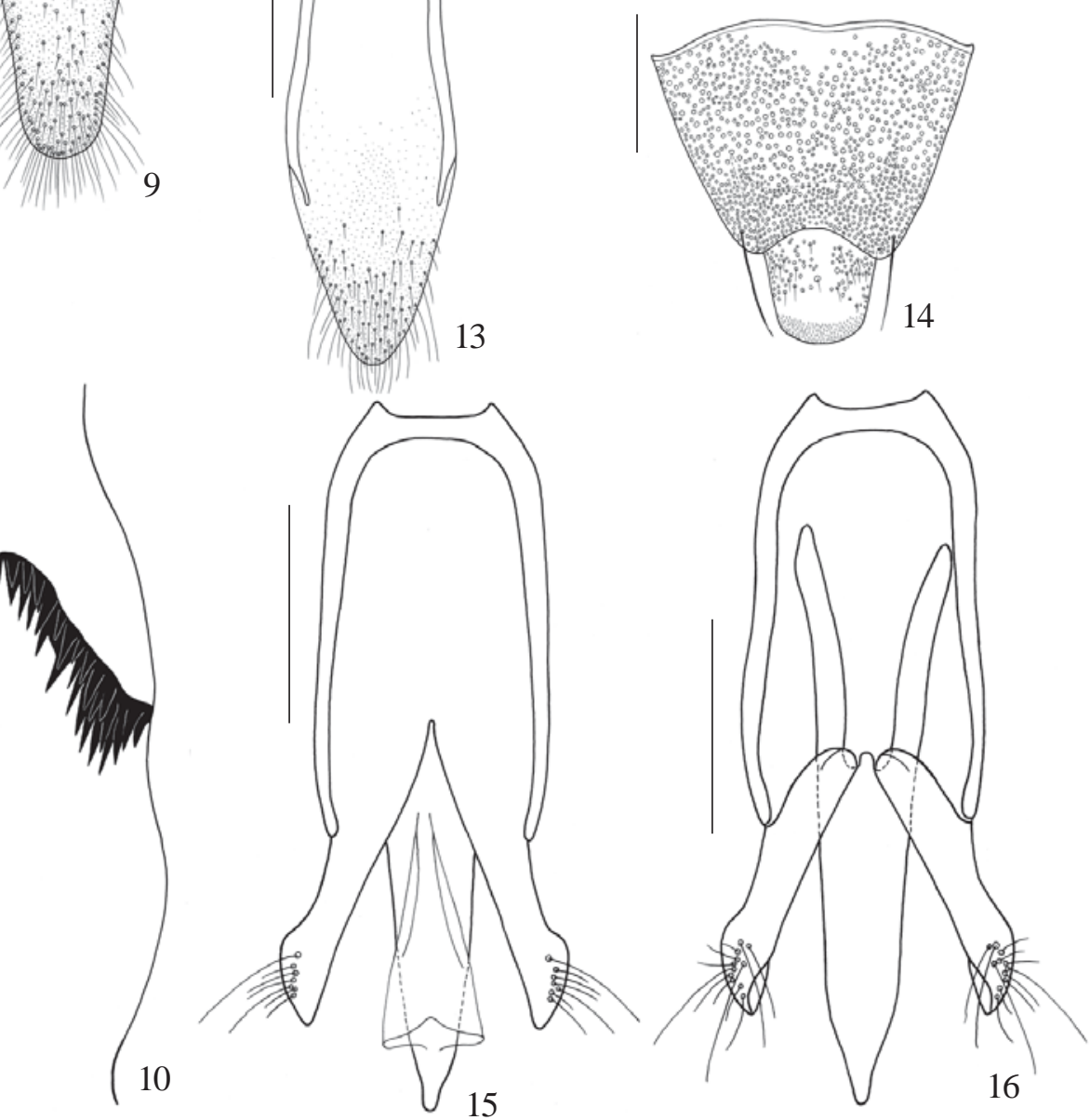

Figs. 1-16. Dicrepidius brasilianus sp. nov. Holotype (male): 1, antenna; 3, frons; 4, last ventrite; 5, pronotum; 6, metacoxal plate; 7, apices of elytra; 11 , tergite $8 ; 12$, sternite $8 ; 13$, sternite $9 ; 14$, tergites $9-10 ; 15,16$, aedeagus (dorsal, ventral). Paratype (female): 2, antenna; 8 , sternite $8 ; 9$, tergite $8 ; 10$, bursa copulatrix and spermatheca. Bars $=5 \mathrm{~mm}$, except figs $1-7=1 \mathrm{~mm}$ and fig. $10=2.5 \mathrm{~mm}$. 


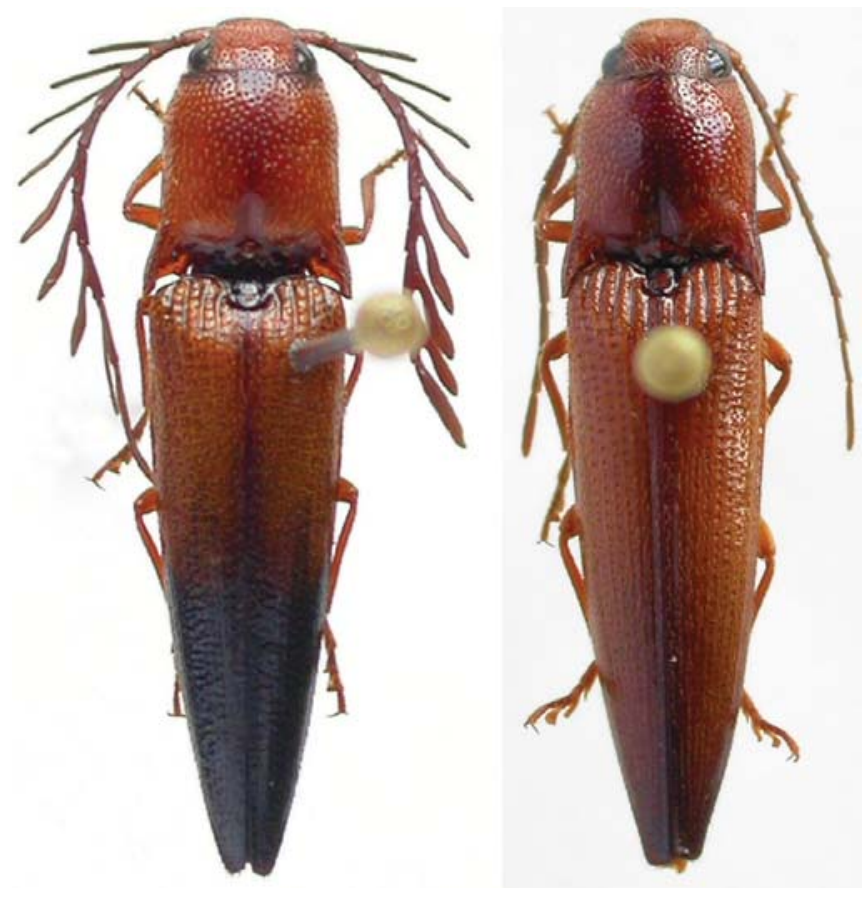

Fig. 17-18. Dicrepidius brasilianus sp. nov. 17, holotype (male); 18, paratype (female). Length, respectively, 13.97 and $16.80 \mathrm{~mm}$.

observed, related especially to coloration, size and density of the punctation. The examined specimens from Panama and South America are darker reddish-brown, usually with a sutural black narrow band on elytra, and the specimens from Florida and Bahamas are brownish or light reddish-brown without the sutural black band on elytra. The larger specimens are from Brazil (14.77-28.38 mm) and the size of the other South America examined specimens vary from $14.36-23.59 \mathrm{~mm}$. The specimens from Florida are smaller and varied from 12.35-18.05 $\mathrm{mm}$ and those from Bahamas, a little smaller, from 11.70-18.74. The punctation of pronotum and scutellar shapes are very variable, independent of the locality. Comparing the aedeagus of specimens of different sizes and localities (including one specimen from type locality: Rio de Janeiro) it was observed only small differences in relation to length/maximum width (length $=4.20-4.7$ times width) and on the density of setae at paramere apices.

Acknowledgments. To curators M. Thomas (FSCA) and R. Valente (MPEG) by sending material as loan and L. Massuti Almeida (DZUP) by permission to examined the collection; Marcelo Duarte (MZSP) by loaning the Electronic Digital caliper; Marcela Monné (Museu Nacional, Universidade Federal do Rio de Janeiro) by taking the copy of the article of Palisot de Beauvois; two referees by comments and suggestions.

\section{REFERENCES}

Blackwelder, R. E. 1944. Checklist of Coleopterous insects of Mexico, Central America, the West Indies and South America. Bulletin of the United States National Museum 185: 280-303.

Bruch. 1911. Catálogo sistemático de los coleópteros de la República Argentina. Revista do Museu de La Plata 17: 143-260.

Candèze, E. 1859. Monographie des Élatérides. Mémoires de la Societé Royale de Sciences de Liège 14: 1-543, 7 pls.

Casari, S. A. 2008. A phylogenetic study of the subtribe Dicrepidiina (Elateridae, Elaterinae, Ampedini). Revista Brasileira de Entomologia 52: 182-260.

Champion, G. C. 1894. Biologia Centrali-Americana. Insecta. Coleoptera. Serricornia. Elateridae. London, Taylor \& Francis. Vol. 3, part 1: 258-440.

Chevrolat, L. A. A. 1867. Coléoptères de 1'Ile de Cuba. (Suite) Notes, synonymies et descriptions d'espèces nouvelles. Septième mémoire. Famille des buprestides, throscides. Eucnémides et élaterides. Annales de la Societé Entomologique de France 7: 571-616.

Golbach, R. 1994. Elateridae (Col.) de la Argentina. Historia, catálogo actualizado hasta 1991 inclusive y clave de subfamilias y de géneros de Centro y Sudamerica. Opera Lilloana 41: 1-48.

Palisot de Beauvois, A. M. F. J. 1805-1821. Insectes recueillis en Afrique et en Amérique, 1805-1821, 276 p., 90 pls. Paris. [From Horn].

Schenkling, S. 1925. Elateridae I. Pars 80. In: Coleopterorum Catalogus auspiciis et auxilio W. Junk. Berlin, W. Junk. 263 p.

Received 03/06/2008; accepted 02/09/2008 